\title{
An AHP method for identifying influential factors on insurance cost
}

\author{
${\text { Firouzeh } \text { Azizi }^{\mathrm{a}^{*}} \text {, Mehdi jafarzadeh kenari }}^{\mathrm{b}}$ and Mehri Nasiri ${ }^{\mathrm{b}}$
}

${ }^{a}$ Department of Management, University of Tarbiat Modarres, Tehran, Iran

${ }^{b}$ Department of Management and Accounting, Allameh Tabatabae'i University, Tehran, Iran

\section{H R O N I C L E}

\section{Article history:}

Received May 25, 2013

Received in revised format

28 June 2013

Accepted 2 August 2013

Available online

August 102013

Keywords:

AHP

Insurance cost

Cost management

\begin{abstract}
A B S T R A C T
During the past few years, there have been increasing competitions in insurance firms around the world and most insurance firms try to find appropriate methods to reduce the cost of their products. In this paper, we perform an empirical investigation to find important factors influencing cost management in insurance industry. The proposed study of this paper detects five items including human productivity, economic inflation, competitions within industry, information technology and rate of damage paid to customers, which are effective on four important cost components. The implementation of analytical hierarchy process on ranking four cost components indicate that the amount of damage paid to customers is the most important factor followed by administration expenses, commission and advertisement.
\end{abstract}

C) 2013 Growing Science Ltd. All rights reserved.

\section{Introduction}

Measuring the performance of insurance firms plays an important role on making strategic decisions in this industry (Klumpes, 2004). There are many studies used for measuring the performance of insurance firms and most of them are involved with various criteria. There are different multi criteria decision making techniques used to find an integrated decisions. Analytical hierarchy process is one of the most popular techniques, which has been widely used by both academics and practitioners (Saaty, 1977, 1988). However, many issues on insurance industry are involved with uncertainty and people may wish to use different methods such as fuzzy logic to handle uncertainty (Shapiro, 2004). The insurance industry has various areas with potential applications for fuzzy logic (FL). These incorporate classification, underwriting, projected liabilities, fuzzy future and present values, pricing, asset allocations and cash flows, and investment. Yücenur and Demirel (2012) presented group decision making process for insurance company selection problem with extended VIKOR method under fuzzy environment. Sayadi et al. (2009) used extension of VIKOR method for decision making problem with interval numbers.

*Corresponding author.

E-mail address: fazizi@modares.ac.ir (F. Azizi) 
Korhonen and Voutilainen (2006) presented some finding on the most preferred alliance structure between banks and insurance companies. Phillips et al. (1998) presented a method for financial pricing of insurance in the multiple-line insurance company. Taksar (2000) presented optimal risk and dividend distribution control models for an insurance company.

\section{The proposed study}

The proposed study of this paper tries to find important factors influencing cost management in insurance industry. The proposed study uses a group of 520 experts and managers who are actively working in Iranian insurance industry. The sample size of this study is determined as follows,

$$
n=\frac{N \times z_{\alpha / 2}^{2} \times p \times q}{\varepsilon^{2} \times(N-1)+z_{\alpha / 2}^{2} \times p \times q},
$$

where $N$ is the population size, $p=1-q$ represents the yes/no categories, $z_{\alpha / 2}$ is CDF of normal distribution and finally $\varepsilon$ is the error term. Since we have $p=0.5, z_{\alpha / 2}=1.96$ and $N=520$, the number of sample size is calculated as $n=384$. The study designs a questionnaire consists of 40 questions and it was first verified by asking some experts to give their insights and then we distribute it among all participants. The quesionnaire also asks decision makers about the effects of two productivity and information technology on reduction of different insurance expenditures.

\section{The results}

We first offer the results of our survey on important productivity and information technology factors on reducing insurance costs. Table 1 summarizes the results of our survey.

\section{Table 1}

The summary of influential factors on cost reduction

\begin{tabular}{|c|c|c|c|}
\hline Item & Description & $\begin{array}{c}\text { Rate of } \\
\text { confirmation }\end{array}$ & $\begin{array}{l}\text { Accept/ } \\
\text { Reject }\end{array}$ \\
\hline 1 & Information technology reduces administration expenditures. & $73 \%$ & $\sqrt{ }$ \\
\hline 2 & Information technology reduces advertisement expenditures. & $78 \%$ & $\sqrt{ }$ \\
\hline 3 & Information technology reduces risks and damages fees. & $59 \%$ & $\sqrt{ }$ \\
\hline 4 & Information technology reduces commission expenses. & $77 \%$ & $\sqrt{ }$ \\
\hline 5 & $\begin{array}{l}\text { Productivity of human resources reduces research and } \\
\text { development expenses. }\end{array}$ & $26 \%$ & $\times$ \\
\hline 6 & Productivity of human resources reduces administration expenses. & $81 \%$ & $\sqrt{ }$ \\
\hline 7 & Productivity of human resources reduces advertisement expenses. & $91 \%$ & $\sqrt{ }$ \\
\hline
\end{tabular}

As we can observe from the results of Table 1, except one case, the effect of human productivity on the costs of research and development, decision makers believe information technology and increase in productivity of human resources could reduce administration, advertisement, risks and damages fees, significantly. These two items, i.e. information technology and human resource productivity, are essential factors detected in the first round of our survey. We have also detected three other factors including competition among insurance firms, inflation rate and insurance coverage percentage are also considered as other important factors in our survey. In addition, four cost items are considered as the most important expenses in insurance industry including administration cost, advertisement cost, damage payable and commission fees paid to retailors. We first compare four cost components in terms of human productivity using analytical hierarchy process (AHP) and the results are summarized in Table 2 as follows, 
Table 2

The results of pairwise comparison and AHP method in terms of human productivity

\begin{tabular}{lcccc}
\hline Cost & Administration & Commissions & Advertisement & Damage paid \\
\hline Weight & 0.369 & 0.321 & 0.179 & 0.137 \\
\hline Consistency ratio & 0.04 & & &
\end{tabular}

The results of Table 2 show that administration cost is the most important factor followed by commissions paid to retailors, advertisement and damage paid. Table 3 presents the results of the same pairwise comparison in terms of competition.

Table 3

The results of pairwise comparison and AHP method in terms of competition factors

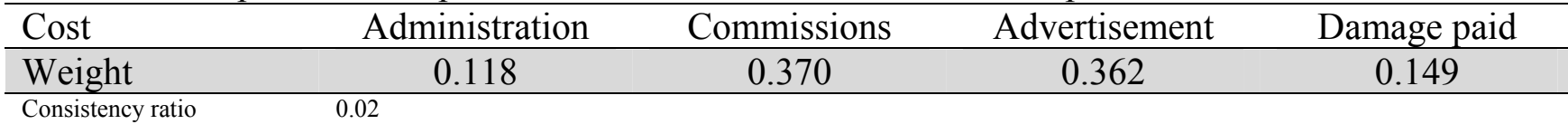

In terms of competition, commission fees are the most important factor followed by advertisement. Next, we compare four cost items in terms of inflation rate and Table 4 shows the results of our survey.

\section{Table 4}

The results of pairwise comparison and AHP method in terms of inflation rate

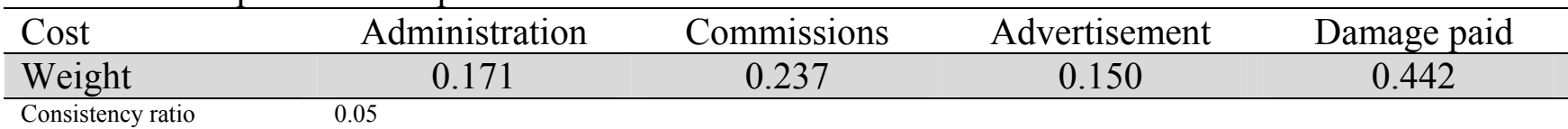

In terms of inflation rate, damage fee paid to customers is the most important factor followed by commissions paid to retailors. Information technology is another factor influencing cost components, which are summarized in Table 5 as follows,

\section{Table 5}

The results of pairwise comparison and AHP method in terms of information technology

\begin{tabular}{|c|c|c|c|c|}
\hline Cost & Administration & Commissions & Advertisement & Damage paid \\
\hline Weight & 0.369 & 0.244 & 0.166 & 0.222 \\
\hline
\end{tabular}

In terms of information technology, administration cost is the most important item followed by commissions, damage paid and advertisement. Finally, rate of damage paid is the last item used for our survey and Table 6 shows details of our results.

\section{Table 6}

The results of pairwise comparison and AHP method in terms of rate of damage paid

\begin{tabular}{|c|c|c|c|c|}
\hline Cost & Administration & Commissions & Advertisement & Damage paid \\
\hline Weight & 0.167 & 0.214 & 0.092 & 0.528 \\
\hline
\end{tabular}

The results of Table 6 clearly show that damage paid to customers is the most important item followed by commissions. Before we make the final ranking, we need to determine the weights of four components.

\section{Table 7}

The results of pairwise comparison and AHP method in terms of five criteria

\begin{tabular}{lccccc}
\hline Cost & $\begin{array}{c}\text { Human } \\
\text { productivity }\end{array}$ & Competition & Inflation rate & $\begin{array}{c}\text { Information } \\
\text { technology }\end{array}$ & $\begin{array}{c}\text { Damage } \\
\text { coverage }\end{array}$ \\
\hline Weight & 0.192 & 0.104 & 0.124 & 0.236 & 0.344 \\
\hline Consistency ratio & 0.04 & & & &
\end{tabular}


After applying the weights of Table 7, we may find ranking of four cost components in Table 8 as follows,

\section{Table 8}

The results of ranking of different cost items

\begin{tabular}{|c|c|c|c|c|}
\hline Cost & Administration & Commissions & Advertisement & Damage paid \\
\hline Weight & 0.247 & 0.261 & 0.161 & 0.33 \\
\hline
\end{tabular}

The results of Table 8 specify that the cost of damage paid to customers is the most important item followed by administration expenses as well as commissions.

\section{Conclusion}

In this paper, we have presented an empirical investigation to find important factors influencing cost management in insurance industry. The proposed study of this paper has detected five items including human productivity, economic inflation, competitions within industry, information technology and rate of damage paid to customers, which are effective on four important cost components. The implementation of AHP on ranking four cost components has revealed that the amount of damage paid to customers is the most important factor followed by administration expenses, commission and advertisement.

\section{References}

Klumpes, P. J. (2004). Performance benchmarking in financial services: Evidence from the UK life insurance industry. The Journal of Business, 77(2), 257-273.

Korhonen, P., \& Voutilainen, R. (2006). Finding the most preferred alliance structure between banks and insurance companies. European Journal of Operational Research, 175(2), 1285-1299.

Phillips, R. D., Cummins, J. D., \& Allen, F. (1998). Financial pricing of insurance in the multiple-line insurance company. Journal of Risk and Insurance, 597-636.

Saaty, T. L. (1977). A scaling method for priorities in hierarchical structures.Journal of mathematical psychology, 15(3), 234-281.

Saaty, T. L. (1988). What is the analytic hierarchy process? (pp. 109-121). Springer Berlin Heidelberg.

Sayadi, M. K., Heydari, M., \& Shahanaghi, K. (2009). Extension of VIKOR method for decision making problem with interval numbers. Applied Mathematical Modelling, 33(5), 2257-2262.

Shapiro, A. F. (2004). Fuzzy logic in insurance. Insurance: Mathematics and Economics, 35(2), 399424.

Taksar, M. I. (2000). Optimal risk and dividend distribution control models for an insurance company. Mathematical methods of operations research, 51(1), 1-42.

Yücenur, G. N., \& Demirel, N. Ç. (2012). Group decision making process for insurance company selection problem with extended VIKOR method under fuzzy environment. Expert Systems with Applications, 39(3), 3702-3707. 